\title{
Case report of cutaneous histiocytic sarcoma: diagnostic and therapeutic dilemmas
}

\author{
Relato de um caso de sarcoma histiocítico cutâneo: dilemas \\ diagnósticos e terapêuticos
}

\author{
Flávia Trevisan ${ }^{1}$ \\ Fernanda Gomes Cattete ${ }^{1}$
}

\author{
Celia Antonia Xavier ${ }^{2}$ \\ Fabíola Schauffler Stock ${ }^{1}$
}

\author{
Clovis Antonio Lopes Pinto ${ }^{3}$ \\ Marcella Ledo Martins ${ }^{1}$
}

\begin{abstract}
Histiocytic sarcoma is a rare hematologic malignant neoplasia originating from histiocytic or dendritic cell clones. The lesions may be in nodal or extranodal sites, most commonly in the gastrointestinal tract. A small number of cases presents as unique cutaneous lesions. The definitive diagnosis is made by positivity for the immunohistochemical markers CD163, CD68, CD4 and lysozyme. The treatment is controversial, often with combined systemic chemotherapy. This is a case of cutaneous histiocytic sarcoma in an 82-year-old patient presenting two nodular lesions in the breast and right arm which were treated with simple excision and multidisciplinary follow-up, avoiding aggressive management and exhaustive investigations. Although most studies report aggressive evolution, the patient had good and stable clinical status during the twelve-month follow-up period.
\end{abstract}

Keywords: Histiocytic disorders, malignant; Histiocytic sarcoma; Immunohistochemistry; Sarcoma; Therapeutics; Treatment outcome

Resumo: Sarcoma histiocítico é uma rara entidade neoplásica maligna hematológica originada de clones celulares dendríticos ou histiocitários. As lesões podem ser nodais ou extranodais, mais comumente no trato gastrintestinal. Um pequeno número de casos apresenta lesões cutâneas exclusivas. O diagnóstico definitivo é feito pela positividade dos marcadores imunohistoquímicos CD163, CD68, CD4 e lisozima. O tratamento é controverso, geralmente com quimioterapia combinada sistêmica. Este é um caso de sarcoma histiocítico cutâneo em uma paciente de 82 anos apresentando duas lesões nodulares na mama e braço direitos, tratadas com exérese simples e seguimento multidisciplinar, evitando-se condutas intempestivas e investigações exaustivas. Apesar de a maioria dos estudos relatar evolução agressiva, a paciente apresenta quadro clínico bom e estável no período de doze meses de seguimento.

Palavras-chave: Imunoistoquímica; Resultado de tratamento; Sarcoma; Sarcoma histiocítico; Terapêutica; Transtornos histiocíticos malignos

\section{INTRODUCTION}

The histiocytic sarcoma (HS) is a hematologic malignancy with histiocytic differentiation classified in a group of neoplasms of dendritic and histiocytic cells. ${ }^{1-4}$ With only a few hundred cases reported, the HS affects adults in the fifth decade of life. ${ }^{2}$ Often synchronous or metachronous with other hematologic malignancies, especially acute myeloid leukemia and follicular lymphoma. ${ }^{1-3}$
Clinically, the HS can affect lymph nodes, gastrointestinal tract, skin, bone marrow, spleen and central nervous system. ${ }^{1-3}$ The symptoms depend on the involved organ. Skin is affected in almost $7 \%$ of the cases, and lesions are described as maculopapular rash, areas of soft consistence on palpation or subcutaneous nodules with central necrosis and ulcers. ${ }^{5}$ The differential diagnosis includes cutaneous lymphomas, carcinomas, melanoma, benign histiocytic prolifera-

Received on 17.08.2012.

Approved by the Advisory Board and accepted for publication on 24.09.2012.

* Work performed at the Dermatology Service, Faculty of Medicine of Jundiaí (Serviço de Dermatologia da Faculdade de Medicina de Jundiaí(FMJ) - Jundiaí (SP), Brazil.

Financial Support: None

Conflict of Interests: None.

MD, resident of Dermatology, Faculty of Medicine of Jundiai (FMJ) - Jundiaí (SP), Brazil.

MS, adjunct professor of Dermatology, Faculty of Medicine of Jundiai (FMJ) - Jundiaí (SP), Brazil.

PhD, adjunct professor of Pathology, Faculty of Medicine of Jundiai (FMJ) - Jundiaí (SP), Brazil. 
tive processes, granulocytic sarcoma and extranodular myeloid tumor. ${ }^{2}$

Histologically, there is a perivascular and periadnexal dermal and subcutaneous histiocytic infiltrate, with cell bundles in some areas. Neoplastic cells are polymorphic, with large and vesicular nuclei, prominent nucleoli and eosinophilic and foamy cytoplasm. Hemophagocytosis may occur and the presence of mitosis is variable. ${ }^{1,5}$ Immunohistochemistry is positive for histiocytic markers such as CD163 and CD68 (Table 1). ${ }^{1}$ CD4, a known marker of T lymphocytes, can also be expressed in cells of the myelomonocytic and histiocytic lineages and is therefore positive in histiocytic sarcoma, although with low specificity. There is also positivity for lysozyme, fascin and CD11c, but there is no expression of markers for B or $\mathrm{T}$ cells, CD1a, S100 and epithelial markers. ${ }^{1-3}$ Rearrangement studies are controversial and in most cases are not necessary. ${ }^{1}$ Bone marrow biopsy is indicated in case of cytopenia or evidence of hemophagocytosis $^{3}$ and acute myeloid leukemia should always be excluded. ${ }^{1,2}$

The course is usually aggressive, with worse prognosis when greater than $3.5 \mathrm{~cm}$ and on advanced stage. ${ }^{1}$ Good progress signals are the absence of cytopenias and liver abnormalities. ${ }^{5}$

Little is known about the therapy, with options ranging from surgical excision with or without radiotherapy in patients with isolated lesions of HS, to systemic combination chemotherapy regimens used to treat lymphoma (CHOP and ICE) and thalidomide. ${ }^{1-3,5}$

\section{CASE REPORT}

An 82-year-old female patient presented since 15 days prior to consultations two asymptomatic nodular and crateriform lesions, about $1.0 \mathrm{~cm}$ wide, covered with central keratosis and crust and erythematous-violaceous infiltrated edges in the right arm and breast (Figures 1 and 2). An excisional biopsy of the lesions was made. The histological diagnosis was of indeterminate malignant neoplasm with deep margins involved and the immunohistochemical examination was positive for CD68, CD4, CD11c, fascin , CD45, CD163 and lysozyme, factor XIIIa was inconclusive and markers of melanin, $B$ and $T$ cells and cytokeratin were negative (Figures 3, 4 and 5). The ultrasonography of soft tissues, breast and axillary lymph nodes and brain and abdomen CT scans showed no signs of neoplastic disease. Tomography of the chest revealed multiple bilateral pulmonary nodules, which were stable in sequential scans and therefore were not biopsied. Other hematological tumors having been excluded, a diagnosis of primary cutaneous histiocytic sarcoma was made. The management included observation of excision sites without expanding margins and periodic oncological and dermatological follow-up. No sign of recurrence was evidenced in the twelve-month follow-up period.

\section{DISCUSSION}

The histiocytic sarcoma is a little discussed entity in dermatology due to the rare cases that have exclusive cutaneous manifestation. Diagnosis was only possible by histopathology and confirmed by immunoreactivity of the neoplastic cells for CD163, CD68, lysozyme and CD4. ${ }^{1,3}$ Therapeutic choices range from simple excision of the lesions with or without radiotherapy to combined systemic chemotherapy. ${ }^{1-3}$ There are no reports of treatment with intralesional chemotherapy, but the authors consider this a viable option still under consideration for small and isolated lesions.

TABLE 1: Immunohistochemical markers in histiocytic sarcoma

\begin{tabular}{llll}
\hline Positive markers & Meaning & Negative markers & Meaning \\
\hline CD4 & Dendritic and Langerhans cells & AE1-AE3 & Cytokeratins \\
CD45 & Common leukocyte antigen & Melan-A & Melanoma antigens \\
CD68 & CD1a & Langerhans cells \\
CD163 & Histiocytes & CD3 & T lymphocytes \\
CD11c & Histiocytes & CD20 & Lymphocytes and epithelial cells \\
Lysozyme* & Dendritic cells & CD23 & B lymphocytes \\
Fascin & Myeloid antigens & CD20 & B lymphocytes \\
& Dendritic cells & CD25 & Mastocytes \\
& & CD30 & B and T activated lymphocytes \\
& & CD34 & Hematopoietic progenitor cells \\
& & MAC387** & Macrophages \\
& & Fator XIIIa** & Dermal dendrocytes \\
\hline
\end{tabular}




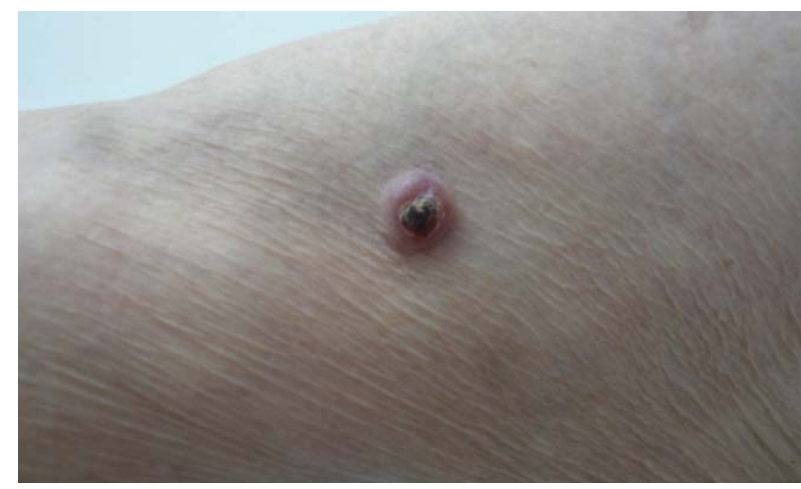

FIGURE 1: Histiocytic sarcoma. Crateriform and nodular lesion, 1.0 $\mathrm{cm}$ wide, covered by keratosis and central crust on the medial side of the right arm

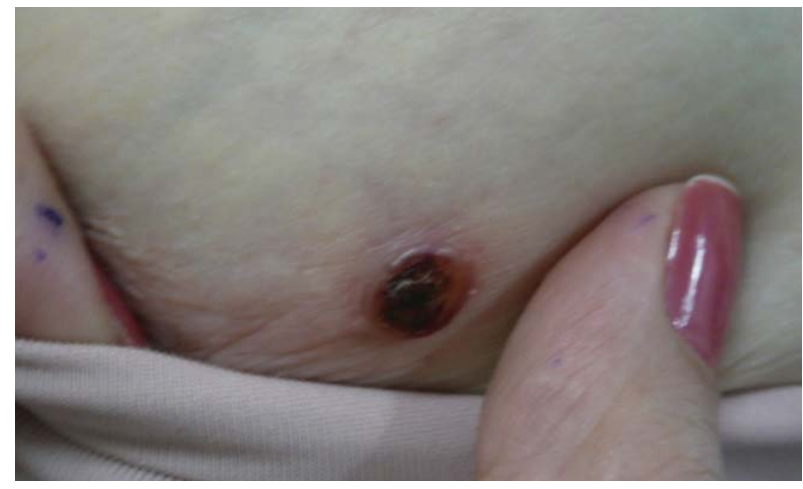

FIgURE 2: Histiocytic sarcoma. Nodular and crateriform lesion, $1.0 \mathrm{~cm}$ wide, covered by keratosis and crust on the right breast

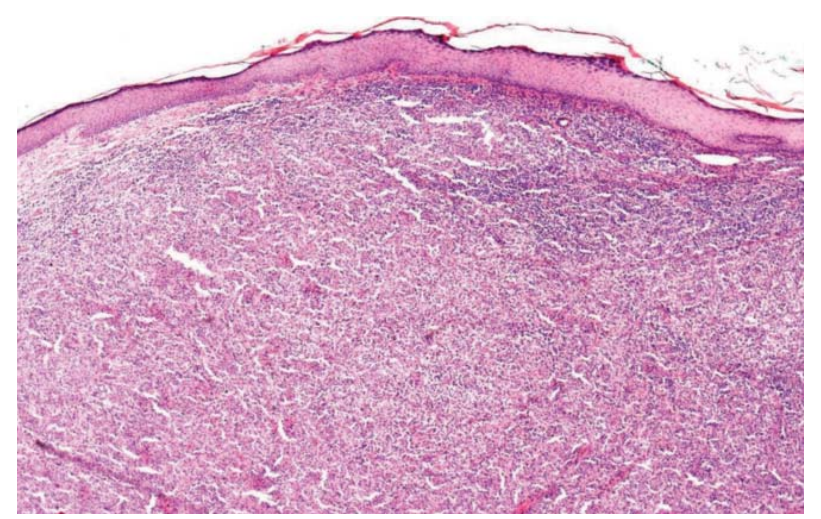

FIGURE 3: Undetermined neoplastic cell proliferation in the dermis. (Hematoxylin-eosin, 40x)

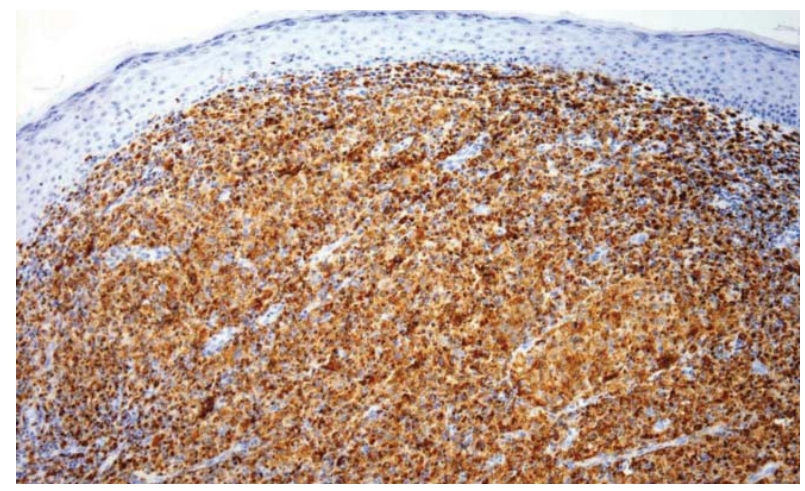

FIGURE 4: Cytoplasm strongly stained for CD68 in malignant dermal cells. (Immunohistochemistry for CD68, 100x)

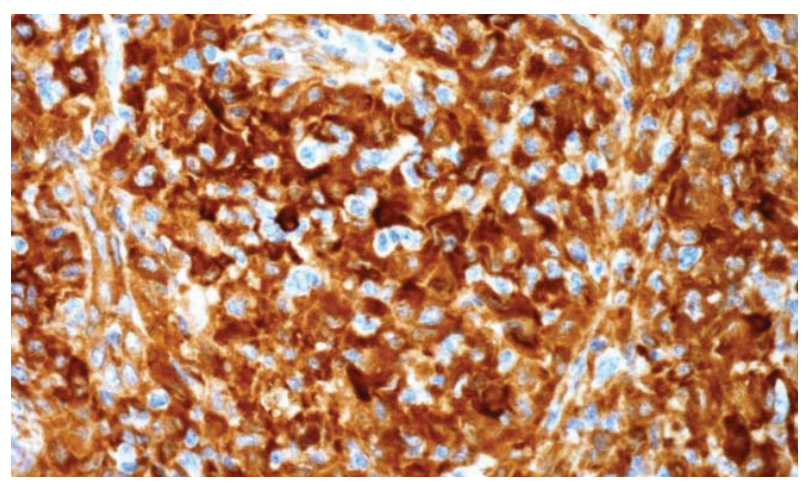

FIGURE 5: Fascin stain strongly positive in cells, some forming fascicles. (Immunohistochemistry for fascin, 100x)

This report is about a patient of advanced age in good clinical condition, with cutaneous histiocytic sarcoma diagnosis and no hematological abnormalities or signs of poor prognosis. Considering that diagnostic investigations and therapeutic options are still controversial issues in the literature, the dilemma of whether to submit the patient to further staging procedures and aggressive treatment was a major concern in the management of this case.

As the patient had no constitutional symptoms or cytopenias, a bone marrow biopsy was postponed and the patient was not subjected to high risk invasive procedures. The sites of lesions are followed clinically at regular intervals of three months. The patient is in excellent clinical condition, without loss of quality of life and no signs of recurrence or systemic involvement in the twelve-month follow-up period. 


\section{REFERENCES}

1. Vos JA, Abbondanzo SL, Barekman CL, Andriko JW, Miettinem M, Aguilera NS. Histiocytic sarcoma: a study of five cases including the histiocyte marker CD163. Mod Pathol. 2005;18:693-704.

2. Schnettker K, Salomone C, Valbuena JR. Cutaneous histiocytic sarcoma: report of one case. Rev Méd Chile. 2009;137:547-51.

3. Jacobson E. Histiocytic sarcoma. UpToDate, updated in February 2012. [cited 2012 Apr 29]. Available from: www.uptodate.com.

4. Lahoti NG, Natarajan A, Karuna R, D'Souza RE. Cutaneous histiocytic lesions: a clinical dilemma. J Postgrad Med. 2000;46:275-7.

5. Swerdlow SH, Campo E, Harris NL, Jaffe ES, Pileri SA, Stein H, et al. World Health Organization Classification of Tumours of Haematopoietic and Lymphoid Tissues. 4th ed. Geneva: IARC WHO Classification of Tumours; 2008. 439 p.

\author{
MAILING ADDRESS: \\ Flávia Trevisan \\ Rua Francisco Telles, 250 - Vila Arens \\ 13202-250 - Jundiaí - SP \\ Brazil \\ E-mail: flaviatrevisan1@yahoo.com.br
}

How to cite this article: Trevisan F, Xavier CA, Pinto CAL, Cattete FG, Stock FS, Martins ML. Case report of cutaneous histiocytic sarcoma: diagnostic and therapeutic dilemmas. An Bras Dermatol. 2013;88(5):807-10. 